\title{
The Promise of Human Induced Pluripotent Stem Cells in Dental Research
}

\author{
Thekkeparambil Chandrabose Srijaya, ${ }^{1,2}$ Padmaja Jayaprasad Pradeep, ${ }^{3}$ \\ Rosnah Binti Zain, ${ }^{3,4}$ Sabri Musa, ${ }^{5}$ Noor Hayaty Abu Kasim, ${ }^{2}$ and Vijayendran Govindasamy ${ }^{5}$ \\ ${ }^{1}$ Research and Development Department, Hygieia Innovation Sdn. Bhd, Lot 1G-2G, Komplex Lanai, No.2, Persiaran Seri Perdana, \\ Persint 10, Territory of Putrajaya, 62250 Federal, Malaysia \\ ${ }^{2}$ Department of Conservative Dentistry, Faculty of Dentistry, University of Malaya, 50603 Kuala Lumpur, Malaysia \\ ${ }^{3}$ Oral Cancer Research and Coordinating Centre (OCRCC), Faculty of Dentistry, University of Malaya, 50603 Kuala Lumpur, Malaysia \\ ${ }^{4}$ Department of Oral Pathology, Oral Medicine and Periodontology, Faculty of Dentistry, University of Malaya, \\ 50603 Kuala Lumpur, Malaysia \\ ${ }^{5}$ Department of Children's Dentistry and Orthodontics, Faculty of Dentistry, University of Malaya, 50603 Kuala Lumpur, Malaysia
}

Correspondence should be addressed to Thekkeparambil Chandrabose Srijaya, sreejayamol@gmail.com

Received 21 November 2011; Revised 20 February 2012; Accepted 22 February 2012

Academic Editor: Rajarshi Pal

Copyright () 2012 Thekkeparambil Chandrabose Srijaya et al. This is an open access article distributed under the Creative Commons Attribution License, which permits unrestricted use, distribution, and reproduction in any medium, provided the original work is properly cited.

\begin{abstract}
Induced pluripotent stem cell-based therapy for treating genetic disorders has become an interesting field of research in recent years. However, there is a paucity of information regarding the applicability of induced pluripotent stem cells in dental research. Recent advances in the use of induced pluripotent stem cells have the potential for developing disease-specific iPSC lines in vitro from patients. Indeed, this has provided a perfect cell source for disease modeling and a better understanding of genetic aberrations, pathogenicity, and drug screening. In this paper, we will summarize the recent progress of the disease-specific iPSC development for various human diseases and try to evaluate the possibility of application of iPS technology in dentistry, including its capacity for reprogramming some genetic orodental diseases. In addition to the easy availability and suitability of dental stem cells, the approach of generating patient-specific pluripotent stem cells will undoubtedly benefit patients suffering from orodental disorders.
\end{abstract}

\section{Introduction}

Human embryonic stem cells (hESCs) are pluripotent cells, which have remarkable proliferation ability to differentiate into any cell types of all three germ layers in a defined culture condition. Hence embryonic stem cells have been regarded as the most potent tool for experimental studies, drug screening, and regenerative medicine [1]. However, the ethical dilemmas regarding the donation or destruction of human embryos and the immunoincompatibility of hESCs have impeded its application in cell-based therapy [1]. In order to overcome these problems, reprogramming techniques have been introduced where somatic cells can be reversed into a pluripotent stem cell-like state. It is generally believed that induced pluripotent stem (iPSC) cells might demonstrate the potential for alleviating incurable diseases and aiding organ transplantation [2].
It has been shown that iPSCs can be derived efficiently from various human cell types [3-8]. An interesting observation is that the transcriptional and epigenetic features of iPSCs are reported to be similar to hESCs [9-11]. Nevertheless, further insights into the inherent similarities and differences between hESCs and iPSCs would be advantageous in understanding the reasons why the use of hESCs in clinical and translational applications has been held back $[12,13]$.

\section{Generation of Induced Pluripotent Stem Cells}

Induced pluripotent stem cells can be produced by forced expression of certain genes by reversing them to a pluripotent state similar to that of embryonic stem cells (ESCs). However, the generation of iPSC requires extremely safe and efficient approaches or strategies to decrease the risk of tumors that may result from the introduction of undifferentiated iPSCs 
into patients. Though such constraints prevail, the approach of generating patient-specific pluripotent cells will undoubtedly benefit regenerative medicine in many ways [14]. The first iPSCs generation was reported by Takahashi and Yamanaka [15] in 2006. They generated the iPSCs through simultaneous overexpression of a group of transcription factors using cell lines derived from mice. A similar genetic manipulation approach was used to generate pluripotent stem cells from human fibroblast cells $[11,13,16]$. In addition to this approach, other modes have also been devised for iPSCs generation including; single polycistronic vector [17], nonintegrating adenoviral APS approaches [18, 19], the PiggyBac transposon system, which removes the transgenes from established iPSC lines after inducing pluripotency [20, 21], the Cre/lox Precombination system [22], and nonintegrating "episomal" vectors that create iPSCs free of vector and transgene DNA [23]. As these methodologies depended solely on foreign DNA transfer into target cells, proteinbased methods have been introduced to address safety issues. In these methods various reprogramming proteins are delivered into cells by conjugating them with a short peptide that mediates protein transduction, such as HIV tat and polyarginine $[24,25]$. In addition, an alternative approach has been described which uses synthetic mRNA to induce pluripotency and differentiation [26]. This new approach showed superior conversion efficiency and kinetics than the earlier described protocols. This mode of cellular reprogramming is a holistic approach as this transfers all the regulatory components from a target cell to a donor cell. Moreover, the cellular reprogramming is achieved by manipulating the whole genome system rather than a small set of master genes.

Therefore finding a safe and efficient mode of iPSCs generation requires a better understanding of the biology of cellular reprogramming. Even though live cells are the phenotypic representations of their genomic state (gene-regulation, epigenetic modifications, and cellular physiology), they do not have a steady molecular state [27]. For this reason, it is possible for the cells to be switched or reprogrammed into a pluripotent state, even in their differentiated form.

\section{Characterization of iPSC Lines}

Generation of iPSC lines were always followed up by subsequent characterizations to ensure the purity and quality of the generated cells and their pluripotency potential. One of the most convenient and direct methods developed for detecting and isolating iPSC was by live immunocytochemistry [28]. Using this technique the characterization of pluripotency can be achieved using intracellular and cell-surface biomarkers such as SSEA-3, SSEA-4, Tra-1-60, and Tra-1-81 [29]. In addition, flow cytometry analyses helps to quantify the expression of these markers at the individual cell level.

In addition to live staining, auxiliary identification was demonstrated using alkaline phosphatase (AP) staining for the reprogramming factors, as AP is a universal marker in the identification of iPSCs [29]. Further evaluation of pluripotency is performed through semiquantitative and quantitative polymerase chain reactions (PCRs) through the expression of both endogenous genes and transgenes [30]. This is followed up by the analysis of methylation status of the promoter region of pluripotent genes by bisulfite sequencing of the CpG islands [29]. Karyotyping analysis is also carried out using standard G-banding chromosome analysis to determine chromosome stability of iPS cell lines [29]. Further, in vitro differentiation of pluripotent stem cells is characterized by the formation of embryoid body followed by teratoma assays [30]. This assay is used to confirm formation of all three embryonic germ layers [30].

\section{Advances in Disease-Specific iPSCs and Their Applications}

Although most of the human-related disease studies are undertaken using rodent models, a genetic defect or disorder produced in human does not necessarily cause the same symptoms in rodents. Therefore, cell cultures from human tissues are considered to be the most suitable complement to animal models. The iPSC technology has made the production of disease-specific stem cells that carry the genome of the donor possible and it mimics the human diseases more reliably than animal models. Apart from generating an in vitro model, disease-specific iPS cell lines from different individuals also allow better understanding of the nature and complexity of a disease. At present the most immediate requirement of such a human disease model is to explore the progression of a disease in different tissues of the human body and also to compare the variability among patients [2].

\section{Existing Types of Disease-Specific iPSC Lines}

A number of studies have been conducted on disease-specific iPSC lines and some of them have provided understanding of the disease mechanisms. Table 1 summarizes the up-to-date literature in which human disease-specific iPSC lines have been generated. The most convincing fact for commencing these studies using iPSC technology was that disease-specific pluripotent cell lines could be generated successfully from patients with a variety of genetic disorders where the iPSC lines had similar characteristic capacity, equivalent to those from a normal individual [11]. Moreover, these iPSC lines were able to differentiate into required cell types of relevant diseases and recapitulate disease-specific effects in vitro which may not be detectable in animal models [31, 32].

\section{Perspective of iPS Technology in Dental Research}

Initially the concept of utilizing iPSCs technology to model disease was mostly emphasized in neural degenerative diseases, which was then extended to other genetic disorders including immune system, muscular, blood, pancreas, skin, bone marrow, liver, lung, retinal, premature ageing, as well as other physical and intellectual disorders. However, the concept of utilizing iPSCs technology is still in its infancy for orodental disorders and diseases. Chronic degenerative dental diseases are widespread in human populations and represent a significant problem for public health. The iPS 
TABLE 1: Disease-specific-induced pluripotent stem cells (iPSCs) lines from various human genetic disorders.

\begin{tabular}{|c|c|c|}
\hline Disease category & Disease & References \\
\hline \multirow{11}{*}{ Neural } & Amyotrophic lateral sclerosis & {$[31]$} \\
\hline & Parkinson's disease & {$[11,22,33,34]$} \\
\hline & Huntington's disease & {$[11,35]$} \\
\hline & Lesch-Nyhan syndrome & {$[11]$} \\
\hline & Rett syndrome & {$[36]$} \\
\hline & Familial dysautonomia & {$[37]$} \\
\hline & Angelman syndrome & {$[38]$} \\
\hline & Prader-Willi syndrome & {$[38,39]$} \\
\hline & Friedreich's ataxia & {$[40]$} \\
\hline & Rett syndrome & {$[41]$} \\
\hline & Schizophrenia & {$[42]$} \\
\hline \multirow{3}{*}{ Immune system } & ADA-SCID & {$[11]$} \\
\hline & Scleroderma & {$[43]$} \\
\hline & Primary immunodeficiency & {$[44]$} \\
\hline \multirow{4}{*}{ Muscular } & Duchenne muscular dystrophy & {$[11]$} \\
\hline & Becker muscular dystrophy & {$[11]$} \\
\hline & Spinal muscular atrophy & {$[25]$} \\
\hline & Duchenne muscular dystrophy & {$[45]$} \\
\hline \multirow{3}{*}{ Blood } & Thalassemia & {$[46,47]$} \\
\hline & Sickle cell anemia & {$[43,47]$} \\
\hline & Chronic myeloid leukemia & {$[48]$} \\
\hline Heart & Long QT syndrome & {$[49,50]$} \\
\hline \multirow{3}{*}{ Pancreas } & Juvenile diabetes mellitus & {$[11]$} \\
\hline & Shwachman-Bodian-Diamond syndrome & {$[11]$} \\
\hline & Type I diabetes & {$[51]$} \\
\hline \multirow{2}{*}{ Skin } & Leopard syndrome & {$[52]$} \\
\hline & Recessive dystrophic, Epidermolysis bullosa & {$[53]$} \\
\hline \multirow{2}{*}{ Bone marrow } & Fanconi anemia & {$[54]$} \\
\hline & Myeloproliferative diseases & {$[54]$} \\
\hline Liver & $\begin{array}{l}\text { Liver diseases: a1-antitrypsin deficiency, familial } \\
\text { hypercholesterolemia, glycogen storagedisease type 1a, Crigler-Najjar, } \\
\text { tyrosinemia type } 1\end{array}$ & {$[55]$} \\
\hline Lung & $\begin{array}{l}\text { Lung diseases: cystic fibrosis, a-1 antitrypsin deficiency-related } \\
\text { emphysema }\end{array}$ & {$[43]$} \\
\hline \multirow{4}{*}{ Others (physical and intellectual limitations) } & Down syndrome & {$[11]$} \\
\hline & Hurler syndrome & {$[44]$} \\
\hline & Gaucher disease & {$[11]$} \\
\hline & Fragile X syndrome & {$[56]$} \\
\hline Premature ageing & Dyskeratosis congenital & [57] \\
\hline \multirow{2}{*}{ Eye } & Retinitis pigmentosa & {$[58]$} \\
\hline & gyrate atrophy & {$[59]$} \\
\hline Dental & $?$ & \\
\hline
\end{tabular}

technology and its application in treating orodental diseases could be a powerful therapeutic tool in dentistry.

Most of the diseases and disorders have a major genetic component. Human diseases and disorders may result from single-gene mutations, but more commonly they are complex as a consequence of multiple gene-gene or gene-environment interactions [60]. The cause of the majority of orodental diseases could be genetically related if infection and traumatic effects are not taken into account. The characteristic signs and symptoms of these diseases indicate genetic origin [61-63], although not all have been clearly identified.

Globally, every year an average of $7 \%$ of infants have some mental or physical defect. Among these, 75\% are related to craniofacial defects or malformations [64]. Again 
it is the dental anomalies that form an integral aspect of such genetic disorders, often representing important clinical clues to the true underlying disorders. Specific examples that are well documented include (1) ectodermal dysplasia [65] with dental manifestations of oligodontia and conical shaped teeth and (2) cleidocranial dysplasia with multiple supernumerary and unerupted teeth $[66,67]$. Therefore, it is necessary for dentists to be aware of the clinical characteristics and the possible alterations that are part of the genetic syndromes, so that they can offer patients multidisciplinary and the best possible treatments. Some of the documented examples of these types of direct or indirect genetic alterations causing dental defects are listed in Table 2.

Possibly, iPSC possess the potential for treating such genetic orodental disorders, confining the availability of suitable disease-specific iPSCs from the diseased person which are able to multiply, cooperate and reform the missing or diseased part. Though, multiple types of stem/progenitor cells have been identified based on their ability to repair/ regenerate and partially restore organ function in the human body, growing evidence illustrates that stem cells are primarily found in niches and that certain tissues contain more stem cells than others [94].

\section{Dental Stem Cell Niches as a Potential Source for Human iPSCs Generation}

The foundation of personalized medicine profoundly lies on procuring the most suitable cell sources. In the human body, various cell sources have been shown to be reprogrammed into iPSC. Among these are dermal fibroblasts, the first of the cell types to be reprogrammed into iPSC, followed by other sources like amniotic fluid-derived cells, skin keratinocytes, embryonic stem cell-derived fibroblasts (ESFs), CD34 blood cells, mesenchymal stem cells (MSCs), and dental pulp [7]. However, studies are showing that it is easier to reprogram more immature cells than somatic cells. Hence immense research was carried out to refine the methodology of iPS technology in terms of techniques, efficiency, and cell type choice. It has been reported that reprogramming efficiency for human fibroblasts is relatively low, while the reprogramming process for keratinocytes generates iPSC colonies 100-fold more efficiently and 2-fold faster as compared to human fibroblasts [95]. The probable cause for such efficacy difference is that keratinocytes have expression levels of stem cell-related genes more similar to ESC than fibroblasts [95].

A similar comparable study reported that dental tissuederived mesenchymal-like stem cells can be reprogrammed into iPSCs more efficiently, when compared to other mature somatic cells from human body such as neonatal foreskin fibroblasts, adult MSCs, and adult dermal fibroblasts [7]. This is probably because of the timing and other factors required for reprogramming a somatic cell to iPS varies greatly depending on cellular context. For example, the reprogramming of MSCs from somatic cell sources mentioned above requires the addition of hTERT (telomerase reverse transferase) and SV40 large-T to turn into iPSCs, whereas dental tissue-derived cells are not confined the same way [7]. Perhaps this emphasizes the use of dental pulp as the most feasible and rich source of mesenchymal stem cells to be used in regenerative therapy, as they are easily available when compared to the tedious collection procedure of other somatic cells.

Dental stem cells can be easily obtained from the pulp of exfoliated primary teeth (SHED) or extracted primary (SCD) and permanent (DPSC), apical papilla (SCAP), tooth germs, and human periodontal ligament. In fact, all these cells can be successfully reprogrammed into iPS cells [94]. A recent report further strengthens the potential of dental-derived stem cells, where reprogramming of human immature dental pulp stem cells (hIDPSCs) was successful within a short-time frame as compared to human fibroblasts, SHED, and DPSC. Furthermore, primary hIDPSC-iPSC colonies were readily obtained even under feeder-free conditions eliminating the possibility of contamination from xenoenvironment [95]. The physiologically intact dental pulp stem cells could be successfully differentiated to advanced derivatives of all three primary germ layers (odontoblast, osteoblast, chondrocyte, myocyte, neurocyte, adipocyte, corneal epithelial cell, melanoma cell, iPSC) (refer review, [94]). Collectively, its multipotency, high proliferation rates, and accessibility make the dental stem cell an attractive source of mesenchymal stem cells for iPS generation. Hence dental-derived stem cells should be considered as a strategy in future regenerative therapies. A schematic representation of the human iPSCs generation from dental stem cells and its applications in various therapeutic approaches is shown in Figure 1.

\section{Therapeutic Potentials of Disease-Specific iPSCs for Genetic Orodental Diseases/Disorders}

Mutations have been shown to play a dominant part in most orodental diseases as tabulated in Table 2 and these genetically caused diseases are the ones that could benefit the most from iPS technology. One of the main focuses of the present stem cell therapy is genetic correction, which would be a permanent solution. For example the iPSCs has shown its therapeutic capability to treat diseases by correcting the underlying genetic defects, which was successfully demonstrated in mouse models of sickle cell anemia [96]. The defective gene was replaced by wild type $\beta$-globin by homologous recombination. Surprisingly, the genetically corrected iPSC-derived hematopoietic progenitor was effective in improving and restoring the physiological function of the diseased animal. This proof of principle was also introduced in human individuals with Fanconi anemia, a disease characterized by severe genetic instability [54]. Hence, this approach can be applied to any genetic disease underlying the human body. Recent studies have also shown the possibilities of developing human endoderm tissuederived iPSC lines. This, along with other established human iPSCs lines, has provided a base to elucidate the mechanisms of cellular reprogramming and also to study the safety as well as efficiency of differentially originated human iPSCs [27]. Studies on liver pathogenesis using iPSCs technology 
TABLe 2: Human genetic oral diseases/disorders causing dental defects.

\begin{tabular}{lll}
\hline Dental disease/disorder & Symptoms & Genetic cause \\
\hline $\begin{array}{l}\text { Orofaciodigital syndrome 1 } \\
\text { (OFD1) }\end{array}$ & $\begin{array}{l}\text { Malformations of the face, oral cavity, oral } \\
\text { clefts, underdeveloped nose flaps, finger } \\
\text { abnormalities, hydronephrosis, and variable } \\
\text { involvement of the central nervous system. }\end{array}$ & $\begin{array}{l}\text { Mutations in OFD1 gene; mutations in } \\
\text { the Cxorf5 gene, located in the Xp22 }\end{array}$ \\
\hline [68-70] \\
$\begin{array}{ll}\text { Oculofaciocardiodental } \\
\text { (OFCD) }\end{array}$ & $\begin{array}{l}\text { Canine radiculomegaly; oligodontia, delayed } \\
\text { eruption of the dentition, malocclusion, root } \\
\text { dilacerations, macrodontia, and enamel } \\
\text { defects; microphthalmia and, congenital } \\
\text { cataracts with secondary glaucoma }\end{array}$ & $\begin{array}{l}\text { Mutations in the BCOR gene located in } \\
\text { the chromosome Xp11.4 }\end{array}$ \\
\hline $\begin{array}{l}\text { Amelogenesis imperfecta } \\
\text { [AI })\end{array}$ & $\begin{array}{l}\text { Developmental abnormalities in the quantity } \\
\text { and/or quality of tooth enamel, occasionally in } \\
\text { conjunction with other dental, oral, and } \\
\text { extraoral tissues }\end{array}$ & $\begin{array}{l}\text { Mutations in any of the six genes } \\
\text { AMELX, ENAM, MMP20, KLK4, } \\
\text { FAM83H, and WDR72 }\end{array}$ \\
\hline Cherubism & $\begin{array}{l}\text { Bilateral bone enlargement of the jaws in } \\
\text { childhood; displacement or aplasia of teeth and } \\
\text { tooth-germs }\end{array}$ & $\begin{array}{l}\text { Mutations in the gene encoding the } \\
\text { binding protein SH3BP2 on chromosome } \\
\text { 4p16.3 }\end{array}$ \\
\hline [74]
\end{tabular}

Disorders of human dentin:

(a) dentinogenesis imperfectas (DI, types I-III)

(b) dentin dysplasias (DD, types I and II)

\begin{tabular}{lll}
\hline Periodontal disease & $\begin{array}{l}\text { Inflammatory as well as recessive alterations of } \\
\text { the gingiva and periodontium }\end{array}$ & Mutation in interleukin-1 (IL-1) gene \\
\hline Hypodontia & $\begin{array}{l}\text { Missing one to six teeth (excluding the third } \\
\text { molars) }\end{array}$ & $\begin{array}{l}\text { Mutations in transcriptions factors of } \\
\text { MSX1 gene in chromosome 4 or another } \\
\text { transcription factor gene PAX9 in } \\
\text { chromosome 14 }\end{array}$ \\
\hline
\end{tabular}

Discoloured teeth (brown-blue or opalescent brown) and structural defects such as bulbous crowns and small pulp chambers

Mutation in dentin sialophosphoprotein gene (DSPP, 4q21.3)

Affects the bones of the face causing a wide skull, a prominent forehead, a flat nose and a small upper jaw; delayed resorption and

Cleidocranial dysplasia (CCD) shedding of primary teeth, delayed maturation, and partial or absent eruption of the permanent teeth combined with ectopic position and development of cysts around the nonerupted molar

\author{
Mutation in the RUNX2 (CBFA1) gene \\ found on chromosome six, $6 \mathrm{p} 21.1$
}

[80-82]
Some dermatological syndrome causing oral and dental manifestation

Hemolytic anemia, photosensitivity (manifested as blistering of the skin), skin

Congenital erythropoietic porphyria fragility, mutilating scarring, hypertrichosis and hyperpigmentation, and deposition of red-brown pigment in the bones and teeth; oral mucosa is pale and the teeth have a red to maroon color

Characterized by the observation of anodontia and hypodontia of the temporal and

Ectodermal dysplasias permanent dentition, impacted teeth, pin-type dental malformations, enamel hypoplasia, multiples diastemas, and underdeveloped alveolar ridges

Repeated blistering, the formation of scars, limitation of oral aperture, ankyloglossia, disappearance of the oral and vestibular sulci,

Epidermolysis bullosa perioral stenosis, severe periodontal disease and bone reabsorption, atrophy of the upper maxilla with mandibular prognathism, an increased mandibular angle, and a predisposition to oral carcinoma
Mutations in the UROS gene which is located in the locus 10q25.2-q26.3

Mutation of Xq12-q13.1 (XLHED-gene) and also mutations in the TP63 gene

Mutations in either the keratin 5 (KRT5) or keratin 14 (KRT14) gene 
Table 2: Continued.

\begin{tabular}{|c|c|c|c|}
\hline Dental disease/disorder & Symptoms & Genetic cause & References \\
\hline Gardner syndrome & $\begin{array}{l}\text { Epidermoid cysts, desmoid tumors, and other } \\
\text { benign tumors; supernumerary teeth, } \\
\text { compound odontomas, hypodontia, abnormal } \\
\text { tooth morphology, and impacted or unerupted } \\
\text { teeth }\end{array}$ & $\begin{array}{l}\text { Mutation in the APC gene located in } \\
\text { chromosome } 5 \mathrm{q} 21 \text {. High-resolution } \\
\text { banding analysis showed an interstitial } \\
\text { deletion of the long arm of chromosome } \\
5(\mathrm{q} 22.1 \rightarrow \mathrm{q} 31.1)\end{array}$ & {$[88]$} \\
\hline Incontinentia pigmenti & $\begin{array}{l}\text { Distinctive swirling pattern of the skin; defects } \\
\text { of teeth, hair, and nails; ophthalmic, central } \\
\text { nervous system, and musculoskeletal } \\
\text { abnormalities }\end{array}$ & $\begin{array}{l}\text { Mutations in the NEMO gene that } \\
\text { completely abolishes expression of } \\
\text { NF-kappaB essential modulator }\end{array}$ & {$[89]$} \\
\hline $\begin{array}{l}\text { Naegeli-Franceschetti- } \\
\text { Jadassohn syndrome }\end{array}$ & $\begin{array}{l}\text { Affects the sweat glands, skin, nails, and teeth; } \\
\text { reticulated hyperpigmentation, hypohidrosis, } \\
\text { palmoplantar hyperkeratosis, abnormal teeth, } \\
\text { and nail dysplasia; abnormally shaped teeth, } \\
\text { polydontia, yellow spotted enamel, caries, and } \\
\text { early total loss }\end{array}$ & $\begin{array}{l}\text { Mutations in the keratin } 14 \text { (KRT14) } \\
\text { gene, located on chromosome } \\
17 \mathrm{q} 11.2-\mathrm{q} 21\end{array}$ & {$[90]$} \\
\hline Papillon-Lefevre syndrome & $\begin{array}{l}\text { Palmoplantar hyperkeratosis and rapid } \\
\text { periodontal destruction }\end{array}$ & $\begin{array}{l}\text { Mutations of a gene that regulates } \\
\text { production of an enzyme known as } \\
\text { cathepsin C, located on the long arm (q) } \\
\text { of chromosome } 11 \text { (11q14-q21) }\end{array}$ & {$[91]$} \\
\hline Sjogren-Larsson syndrome & $\begin{array}{l}\text { Congenital ichthyosis, spastic diplegia or } \\
\text { quadriplegia, and mental retardation; white } \\
\text { dots in the fundus, speech defects, epilepsy, } \\
\text { dental problems, and skeletal abnormalities }\end{array}$ & $\begin{array}{l}\text { Mutations in the FALDH (ALDH3A2) } \\
\text { gene on chromosome } 17 \text { p11.2 }\end{array}$ & {$[92,93]$} \\
\hline
\end{tabular}

have provided a more amenable system to generate liver disease-specific cell lines. The ability to develop such diseasespecific stem cell models can be utilized for disease modeling which helps in the study of the complicated pathogenesis and drug screening purposes [27]. Similarly, studies have also been undertaken for neural degenerative diseases like Parkinson's disease and retinal disease (Retinitis pigmentosa; gyrate atrophy) (Table 1).

Most clinical therapies and treatments on disorders of neural, retinal, hepatic, diabetic, bone, and tissue aberrations are mostly focused on only particular tissue aspects of human body. However, some of these disorders have orodental manifestations. Moreover, most of the identified genetic orodental diseases are also encountered with similar problems as those of other disorders. In this context, the use of iPSC therapy for treating such disorders that were applied earlier can also be considered for orodental diseases. The promise of regenerative medicine in orodental disease is reinforced with the potential applicability of stem cell therapy in dentistry, which could provide an ideal solution to certain prevailing problems. For example, an immature tooth with extensive coronal and pulp damage could be reversible through regeneration of tooth tissues. Similarly, regeneration of resorbed root, cervical, or apical dentin, periodontal regeneration, whole-tooth regeneration, repair and replacement of bone in craniofacial defects can facilitate restoring the physiologic structural integrity [97]. For instance, the successful regeneration of periodontal tissue, alveolar bone, cementum, and periodontal ligament has been achieved using autologous periodontal ligament mesenchymal stem cells (PDL-MSCs), with no adverse effect when transplanted [98]. Considering the success of such attempts using tissue engineering techniques, by applying the advanced iPS cell technology, more fruitful advantage can be expected for their use in cell transplantation therapies and gene corrections in orodental disorders.

The regeneration of orodental tissues is dependent on four basic components. The appropriate signals, cells, blood supply, and scaffold that are needed to target the tissue at the site of defect [99]. These four elements play a fundamental role in the reconstruction and healing of lost tissues. The cells provide the machinery for new tissue growth and differentiation, whereas the growth factors modulate the cellular activity and stimulate the cells to differentiate as well as produce tissue matrix [99]. The new vascular tissues provide the nutritional base for tissue growth and the scaffolds guide and create a template structure in three-dimensions to facilitate the tissue regeneration process [99]. Tissue engineering strategies using this basic cell transplantation approach can be successfully applied for a wide variety of oral structures such as bone, periodontal ligament, oral mucosa, skin, and teeth. In addition, such cells can also be genetically modified ex vivo by using iPS technology and thereby merging stem cell technology and precision gene therapy, a new therapeutic approach for oral genetic disorders is possible. This impulses the possibility of their use in iPS technology, since they can be utilized not only for dental associated problems, but may facilitate the repair of nondental tissues such as bones and nerves $[61,100,101]$.

Hence, if we could attempt the real possibility of ex vivo genetic manipulations, iPSCs will be the most powerful therapeutic tools for a variety of dental pathologies which have yet to be investigated. In this regard, it is valuable to establish disease-specific iPSC lines, preferably for the genetic 


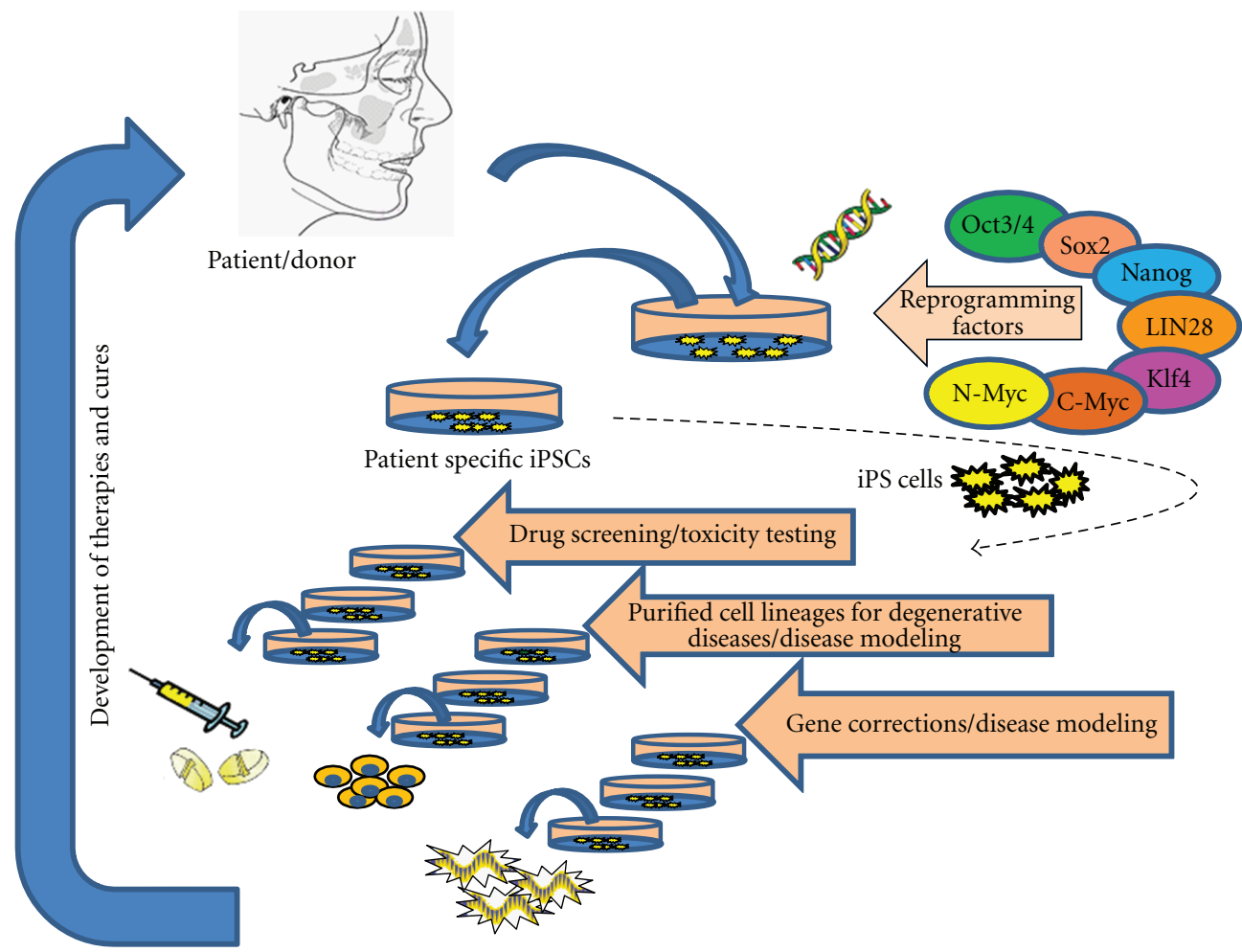

FIgURE 1: A schematic representation of the human iPSCs generation.

dental disorders to comprehensively evaluate their disease modeling potentials. Therefore fundamental research program is needed to ascertain the application of iPS technology in genetic orodental disorders, which requires extensive programs that can be directed to each aspect of dental diseases and its genetic cause.

\section{Conclusion}

Though studies have reported the successful generation of disease-specific iPSC lines from individuals with different diseases, effective disease modeling has been demonstrated only by a few studies. The development of iPSC models for orodental diseases is still a new concept. The availability of such iPSC models will lead to better understanding of the nature and behavior of orodental diseases. Possibly the opportunities for the exploration of iPS technology in treating orodental diseases will lead to a significant benefit for the population at large.

\section{Acknowledgment}

The work is part of an ongoing project supported by University of Malaya, High Impact Research-Ministry of Higher Education, Malaysia (UM.C/HIR/MOHE/DENT/01).

\section{References}

[1] X. Chen and F. Zeng, "Directed hepatic differentiation from embryonic stem cells," Protein and Cell, vol. 2, no. 3, pp. 180 $188,2011$.
[2] W. Deng, "Induced pluripotent stem cells: paths to new medicines," EMBO Reports, vol. 11, no. 3, pp. 161-165, 2010.

[3] T. Aasen, A. Raya, M. J. Barrero et al., "Efficient and rapid generation of induced pluripotent stem cells from human keratinocytes," Nature Biotechnology, vol. 26, no. 11, pp. 1276-1284, 2008.

[4] W. E. Lowry, L. Richter, R. Yachechko et al., "Generation of human induced pluripotent stem cells from dermal fibroblasts," Proceedings of the National Academy of Sciences of the United States of America, vol. 105, no. 8, pp. 2883-2888, 2008.

[5] Y. H. Loh, S. Agarwal, I. H. Park et al., "Generation of induced pluripotent stem cells from human blood," Blood, vol. 113, no. 22, pp. 5476-5479, 2009.

[6] A. Haase, R. Olmer, K. Schwanke et al., "Generation of induced pluripotent stem cells from human cord blood," Cell Stem Cell, vol. 5, no. 4, pp. 434-441, 2009.

[7] X. Yan, H. Qin, C. Qu, R. S. Tuan, S. Shi, and G. T. J. Huang, "iPs cells reprogrammed from human mesenchymallike stem/progenitor cells of dental tissue origin," Stem Cells and Development, vol. 19, no. 4, pp. 469-480, 2010.

[8] A. Kunisato, M. Wakatsuki, H. Shinba, T. Ota, I. Ishida, and K. Nagao, "Direct generation of induced pluripotent stem cells from human nonmobilized blood," Stem Cells and Development, vol. 20, no. 1, pp. 159-168, 2011.

[9] N. Maherali, R. Sridharan, W. Xie et al., "Directly reprogrammed fibroblasts show global epigenetic remodeling and widespread tissue contribution," Cell Stem Cell, vol. 1, no. 1, pp. 55-70, 2007.

[10] K. Okita, T. Ichisaka, and S. Yamanaka, "Generation of germline-competent induced pluripotent stem cells," Nature, vol. 448, no. 7151, pp. 313-317, 2007. 
[11] I. H. Park, N. Arora, H. Huo et al., "Disease-specific induced pluripotent stem cells," Cell, vol. 134, no. 5, pp. 877-886, 2008.

[12] S. M. Wu and K. Hochedlinger, "Harnessing the potential of induced pluripotent stem cells for regenerative medicine," Nature Cell Biology, vol. 13, no. 5, pp. 497-505, 2011.

[13] K. Takahashi, K. Tanabe, M. Ohnuki et al., "Induction of pluripotent stem cells from adult human fibroblasts by defined factors," Cell, vol. 131, no. 5, pp. 861-872, 2007.

[14] G. Amabile and A. Meissner, "Induced pluripotent stem cells: current progress and potential for regenerative medicine," Trends in Molecular Medicine, vol. 15, no. 2, pp. 59-68, 2009.

[15] K. Takahashi and S. Yamanaka, "Induction of pluripotent stem cells from mouse embryonic and adult fibroblast cultures by defined factors," Cell, vol. 126, no. 4, pp. 663-676, 2006.

[16] J. Yu, M. A. Vodyanik, K. S. Otto et al., "Induced pluripotent stem cell lines derived from human somatic cells," Science, vol. 318, no. 5858, pp. 1917-1920, 2007.

[17] B. W. Carey, S. Markoulaki, J. Hanna et al., "Reprogramming of murine and human somatic cells using a single polycistronic vector," Proceedings of the National Academy of Sciences of the United States of America, vol. 106, no. 1, pp. 157-162, 2009.

[18] K. Okita, M. Nakagawa, H. Hyenjong, T. Ichisaka, and S. Yamanaka, "Generation of mouse induced pluripotent stem cells without viral vectors," Science, vol. 322, no. 5903, pp. 949-953, 2008.

[19] M. Stadtfeld, M. Nagaya, J. Utikal, G. Weir, and K. Hochedlinger, "Induced pluripotent stem cells generated without viral integration," Science, vol. 322, no. 5903, pp. 945-949, 2008.

[20] K. Kaji, K. Norrby, A. Paca, M. Mileikovsky, P. Mohseni, and K. Woltjen, "Virus-free induction of pluripotency and subsequent excision of reprogramming factors," Nature, vol. 458, no. 7239, pp. 771-775, 2009.

[21] K. Woltjen, I. P. Michael, P. Mohseni et al., "PiggyBac transposition reprograms fibroblasts to induced pluripotent stem cells," Nature, vol. 458, no. 7239, pp. 766-770, 2009.

[22] F. Soldner, D. Hockemeyer, C. Beard et al., "Parkinson's disease patient-derived induced pluripotent stem cells free of viral reprogramming factors," Cell, vol. 136, no. 5, pp. 964977, 2009.

[23] J. Yu, K. Hu, K. S. Otto et al., "Human induced pluripotent stem cells free of vector and transgene sequences," Science, vol. 324, no. 5928, pp. 797-801, 2009.

[24] D. Kim, J. I. Moon, Y. G. Chung et al., "Generation of human induced pluripotent stem cells by direct delivery of reprogramming proteins," Cell Stem Cell, vol. 4, no. 6, pp. 472-476, 2009.

[25] H. Zhou, S. Wu, J. Y. Joo et al., "Generation of induced pluripotent stem cells using recombinant proteins," Cell Stem Cell, vol. 4, no. 5, pp. 381-384, 2009.

[26] L. Warren, P. D. Manos, T. Ahfeldt et al., "Highly efficient reprogramming to pluripotency and directed differentiation of human cells with synthetic modified mRNA," Cell Stem Cell, vol. 7, no. 5, pp. 618-630, 2010.

[27] Y. S. Chun, P. Chaudhari, and Y. Y. Jang, "Applications of patient-specific induced pluripotent stem cells; focused on disease modeling, drug screening and therapeutic potentials for liver disease," International Journal of Biological Sciences, vol. 6, no. 7, pp. 796-805, 2010.
[28] N. Y. Kang, S. W. Yun, H. H. Ha, S. J. Park, and Y. T. Chang, "Embryonic and induced pluripotent stem cell staining and sorting with the live-cell fluorescence imaging probe CDy1," Nature Protocols, vol. 6, no. 7, pp. 1044-1052, 2011.

[29] J. Yu, K. F. Chau, M. A. Vodyanik, J. Jiang, and Y. Jiang, "Efficient feeder-free episomal reprogramming with small molecules," Plos one, vol. 6, no. 3, Article ID e17557, 2011.

[30] M. Ohnuki, K. Takahashi, and S. Yamanaka, "Generation and characterization of human induced pluripotent stem cells," Current Protocols in Stem Cell Biology, vol. 4, pp. 4A.2.14A.2.25, 2009.

[31] J. T. Dimos, K. T. Rodolfa, K. K. Niakan et al., "Induced pluripotent stem cells generated from patients with ALS can be differentiated into motor neurons," Science, vol. 321, no. 5893, pp. 1218-1221, 2008.

[32] A. D. Ebert, J. Yu Jr., F. F. Rose et al., "Induced pluripotent stem cells from a spinal muscular atrophy patient," Nature, vol. 457, no. 7227, pp. 277-280, 2009.

[33] O. Cooper, G. Hargus, M. Deleidi et al., "Differentiation of human ES and parkinson's disease iPS cells into ventral midbrain dopaminergic neurons requires a high activity form of SHH, FGF8a and specific regionalization by retinoic acid," Molecular and Cellular Neuroscience, vol. 45, no. 3, pp. 258-266, 2010.

[34] G. Hargus, O. Cooper, M. Deleidi et al., "Differentiated parkinson patient-derived induced pluripotent stem cells grow in the adult rodent brain and reduce motor asymmetry in parkinsonian rats," Proceedings of the National Academy of Sciences of the United States of America, vol. 107, no. 36, pp. 15921-15926, 2010.

[35] N. Zhang, M. C. An, D. Montoro, and L. M. Ellerby, "Characterization of human Huntington's disease cell model from induced pluripotent stem cells," PLoS Currents, vol. 2, Article ID RRN1193, 2010.

[36] A. Hotta, A. Y. L. Cheung, N. Farra et al., "Isolation of human iPS cells using EOS lentiviral vectors to select for pluripotency," Nature Methods, vol. 6, no. 5, pp. 370-376, 2009.

[37] G. Lee, E. P. Papapetrou, H. Kim et al., "Modelling pathogenesis and treatment of familial dysautonomia using patientspecific iPSCs," Nature, vol. 461, no. 7262, pp. 402-406, 2009.

[38] S. J. Chamberlain, P. F. Chen, K. Y. Ng et al., "Induced pluripotent stem cell models of the genomic imprinting disorders angelman and prader-willi syndromes," Proceedings of the National Academy of Sciences of the United States of America, vol. 107, no. 41, pp. 17668-17673, 2010.

[39] J. Yang, J. Cai, Y. Zhang et al., "Induced pluripotent stem cells can be used to model the genomic imprinting disorder Prader-Willi syndrome," The Journal of Biological Chemistry, vol. 285, no. 51, pp. 40303-40311, 2010.

[40] S. Ku, E. Soragni, E. Campau et al., "Friedreich's ataxia induced pluripotent stem cells model intergenerational GAATTC triplet repeat instability," Cell Stem Cell, vol. 7, no. 5, pp. 631-637, 2010.

[41] M. C. N. Marchetto, C. Carromeu, A. Acab et al., "A model for neural development and treatment of Rett syndrome using human induced pluripotent stem cells," Cell, vol. 143, no. 4, pp. 527-539, 2010.

[42] K. J. Brennand, A. Simone, J. Jou et al., "Modelling schizophrenia using human induced pluripotent stem cells," Nature, vol. 473, no. 7346, pp. 221-225, 2011. 
[43] A. Somers, J. C. Jean, C. A. Sommer et al., "Generation of transgene-free lung disease-specific human induced pluripotent stem cells using a single excisable lentiviral stem cell cassette," Stem Cells, vol. 28, no. 10, pp. 1728-1740, 2010.

[44] I. M. Pessach, J. Ordovas-Montanes, S. Y. Zhang et al., "Induced pluripotent stem cells: a novel frontier in the study of human primary immunodeficiencies," Journal of Allergy and Clinical Immunology, vol. 127, no. 6, pp. 1400-1407, 2011.

[45] Y. Kazuki, M. Hiratsuka, M. Takiguchi et al., "Complete genetic correction of ips cells from duchenne muscular dystrophy," Molecular Therapy, vol. 18, no. 2, pp. 386-393, 2010.

[46] Y. Wang, Y. Jiang, S. Liu, X. Sun, and S. Gao, "Generation of induced pluripotent stem cells from human $\beta$-thalassemia fibroblast cells," Cell Research, vol. 19, no. 9, pp. 1120-1123, 2009.

[47] L. Ye, J. C. Chang, C. Lin, X. Sun, J. Yu, and Y. W. Kan, "Induced pluripotent stem cells offer new approach to therapy in thalassemia and sickle cell anemia and option in prenatal diagnosis in genetic diseases," Proceedings of the National Academy of Sciences of the United States of America, vol. 106, no. 24, pp. 9826-9830, 2009.

[48] J. E. Carette, J. Pruszak, M. Varadarajan et al., "Generation of iPSCs from cultured human malignant cells," Blood, vol. 115, no. 20, pp. 4039-4042, 2010.

[49] A. Moretti, M. Bellin, A. Welling et al., "Patient-specific induced pluripotent stem-cell models for long-QT syndrome," New England Journal of Medicine, vol. 363, no. 15, pp. 1397-1409, 2010.

[50] I. Itzhaki, L. Maizels, I. Huber et al., "Modelling the long QT syndrome with induced pluripotent stem cells," Nature, vol. 471, no. 7337, pp. 225-239, 2011.

[51] R. Maehr, S. Chen, M. Snitow et al., "Generation of pluripotent stem cells from patients with type 1 diabetes," Proceedings of the National Academy of Sciences of the United States of America, vol. 106, no. 37, pp. 15768-15773, 2009.

[52] X. Carvajal-Vergara, A. Sevilla, S. L. D’Souza et al., "Patientspecific induced pluripotent stem-cell-derived models of LEOPARD syndrome," Nature, vol. 465, no. 7299, pp. 808 $812,2010$.

[53] J. Tolar, I. H. Park, L. Xia et al., "Hematopoietic differentiation of induced pluripotent stem cells from patients with mucopolysaccharidosis type I (Hurler syndrome)," Blood, vol. 117, no. 3, pp. 839-847, 2011.

[54] A. Raya, I. Rodriguez-Piz, G. Guenechea et al., "Diseasecorrected haematopoietic progenitors from Fanconi anaemia induced pluripotent stem cells," Nature, vol. 460, no. 7251, pp. 53-59, 2009.

[55] S. T. Rashid, S. Corbineau, N. Hannan et al., "Modeling inherited metabolic disorders of the liver using human induced pluripotent stem cells," Journal of Clinical Investigation, vol. 120, no. 9, pp. 3127-3136, 2010.

[56] A. Urbach, O. Bar-Nur, G. Q. Daley, and N. Benvenisty, "Differential modeling of fragile $\mathrm{X}$ syndrome by human embryonic stem cells and induced pluripotent stem cells," Cell Stem Cell, vol. 6, no. 5, pp. 407-411, 2010.

[57] S. Agarwal, Y. H. Loh, E. M. McLoughlin et al., "Telomere elongation in induced pluripotent stem cells from dyskeratosis congenita patients," Nature, vol. 464, no. 7286, pp. 292296, 2010.

[58] Z. B. Jin, S. Okamoto, F. Osakada et al., "Modeling retinal degeneration using patient-specific induced pluripotent stem cells," PloS One, vol. 6, no. 2, Article ID e17084, 2011.
[59] J. S. Meyer, S. E. Howden, K. A. Wallace et al., "Optic vesiclelike structures derived from human pluripotent stem cells facilitate a customized approach to retinal disease treatment," Stem Cells, vol. 29, no. 8, pp. 1206-1218, 2011.

[60] H. C. Slavkin, "The human genome, implications for oral health and diseases, and dental education," Journal of Dental Education, vol. 65, no. 5, pp. 463-479, 2001.

[61] H. O. Sedano, C. Freyre, M. L. Garza de la Garza et al., "Clinical orodental abnormalities in Mexican children," Oral Surgery Oral Medicine and Oral Pathology, vol. 68, no. 3, pp. 300-311, 1989.

[62] A. Mostowska, A. Kobielak, and W. H. Trzeciak, "Molecular basis of non-syndromic tooth agenesis: mutations of MSX1 and PAX9 reflect their role in patterning human dentition," European Journal of Oral Sciences, vol. 111, no. 5, pp. 365$370,2003$.

[63] B. L. Pihlstrom, B. S. Michalowicz, and N. W. Johnson, "Periodontal diseases," The Lancet, vol. 366, no. 9499, pp. 1809-1820, 2005.

[64] P. E. Petersen, D. Bourgeois, H. Ogawa, S. Estupinan-Day, and C. Ndiaye, "The global burden of oral diseases and risks to oral health," Bulletin of the World Health Organization, vol. 83, no. 9, pp. 661-669, 2005.

[65] P. J. M. Crawford, M. J. Aldred, and A. Clarke, "Clinical and radiographic dental findings in $\mathrm{X}$ linked hypohidrotic ectodermal dysplasia," Journal of Medical Genetics, vol. 28, no. 3, pp. 181-185, 1991.

[66] B. S. Gonzalez Lepez, C. Ortiz Solalinde, T. I. Kubodera, E. Lara Carrillo, and E. Ortiz Solalinde, "Cleido cranial dysplasia: report of a family," Journal of Oral Science, vol. 46, no. 4, pp. 259-266, 2004.

[67] M. M. Cohen Jr. and S. Kreiborg, "Perspectives on craniofacial syndromes," Acta Odontologica Scandinavica, vol. 56, no. 6, pp. 315-320, 1998.

[68] H. V. Toriello, "Oral-facial-digital syndromes," Clinical Dysmorphology, vol. 2, no. 2, pp. 95-105, 1992.

[69] S. A. Feather, A. S. Woolf, D. Donnai, S. Malcolm, and R. M. Winter, "The oral-facial-digital syndrome type 1 (OFD1), a cause of polycystic kidney disease and associated malformations, maps to Xp22.2-Xp22.3," Human Molecular Genetics, vol. 6, no. 7, pp. 1163-1167, 1997.

[70] M. I. Ferrante, G. Giorgio, S. A. Feather et al., "Identification of the gene for oral-facial-digital type 1 syndrome," American Journal of Human Genetics, vol. 68, no. 3, pp. 569-576, 2001.

[71] P. Hedera and J. L. Gorski, "Oculo-facio-cardio-dental syndrome: skewed X chromosome inactivation in mother and daughter suggest X-linked dominant inheritance," American Journal of Medical Genetics, vol. 123, no. 3, pp. 261-266, 2003.

[72] E. McGovern, M. AL-Mudaffer, C. McMahon, D. Brosnahan, P. Fleming, and W. Reardon, "Oculo-facio-cardio-dental syndrome in a mother and daughter," International Journal of Oral and Maxillofacial Surgery, vol. 35, no. 11, pp. 10601062, 2006.

[73] J. T. Wright, M. J. Aldred, K. Seow et al., "Relationship of phenotype and genotype in X-linked amelogenesis imperfecta," Connective Tissue Research, vol. 44, no. 1, pp. 72-78, 2003.

[74] J. Mangion, N. Rahman, S. Edkins et al., "The gene for cherubism maps to chromosome 4p16.3," American Journal of Human Genetics, vol. 65, no. 1, pp. 151-157, 1999.

[75] M. L. Beattie, J. W. Kim, S. G. Gong, C. A. Murdoch-Kinch, J. P. Simmer, and J. C. C. Hu, "Phenotypic variation in dentinogenesis imperfecta/dentin dysplasia linked to 4q21," Journal of Dental Research, vol. 85, no. 4, pp. 329-333, 2006. 
[76] K. S. Kornman, A. Crane, H. Y. Wang et al., "The interleukin1 genotype as a severity factor in adult periodontal disease," Journal of Clinical Periodontology, vol. 24, no. 1, pp. 72-77, 1997.

[77] C. C. Pontes, J. R. Gonzales, A. B. Novaes et al., "Interleukin4 gene polymorphism and its relation to periodontal disease in a Brazilian population of African heritage," Journal of Dentistry, vol. 32, no. 3, pp. 241-246, 2004.

[78] P. Das, D. W. Stockton, C. Bauer et al., "Haploinsufficiency of PAX9 is associated with autosomal dominant hypodontia," Human Genetics, vol. 110, no. 4, pp. 371-376, 2002.

[79] L. Lammi, K. Halonen, S. Pirinen, I. Thesleff, S. Arte, and P. Nieminen, "A missense mutation in PAX9 in a family with distinct phenotype of oligodontia," European Journal of Human Genetics, vol. 11, no. 11, pp. 866-871, 2003.

[80] T. Yoshida, H. Kanegane, M. Osato et al., "Functional analysis of RUNX2 mutations in Japanese patients with cleidocranial dysplasia demonstrates novel genotype-phenotype correlations," American Journal of Human Genetics, vol. 71, no. 4, pp. 724-738, 2002.

[81] R. Mendoza-Londono and R. Lee, "Cleidocranial dysplasia," Gene Reviews, Bookshelf ID: NBK1513, 2009, http://www .genetests.org.

[82] J. K. Northup, R. Matalon, L. H. Lockhart, J. C. Hawkins, and G. V. N. Velagaleti, "A complex chromosome rearrangement, der(6)ins(6)(p21.1q25.3q27)inv(6)(p25.3q27), in a child with cleidocranial dysplasia," European Journal of Medical Genetics, vol. 54, no. 4, pp. e394-e398, 2011.

[83] C. Ged, H. Megarbane, E. Chouery, M. Lalanne, A. Megarbane, and H. de Verneuil, "Congenital erythropoietic porphyria: report of a novel mutation with absence of clinical manifestations in a homozygous mutant sibling," Journal of Investigative Dermatology, vol. 123, no. 3, pp. 589-591, 2004.

[84] J. Kere, A. K. Srivastava, O. Montonen et al., "X-linked anhidrotic (hypohidrotic) ectodermal dysplasia is caused by mutation in a novel transmembrane protein," Nature Genetics, vol. 13, no. 4, pp. 409-416, 1996.

[85] J. Amiel, G. Bougeard, C. Francannet et al., "TP63 gene mutation in ADULT syndrome," European Journal of Human Genetics, vol. 9, no. 8, pp. 642-645, 2001.

[86] J. D. Fine, R. A. J. Eady, E. A. Bauer et al., "Revised classification system for inherited epidermolysis bullosa: report of the Second International Consensus Meeting on diagnosis and classification of epidermolysis bullosa," Journal of the American Academy of Dermatology, vol. 42, no. 6, pp. 10511066, 2000.

[87] R. E. Cummins, S. Klingberg, J. Wesley, M. Rogers, Y. Zhao, and D. F. Murrell, "Keratin 14 point mutations at codon 119 of helix 1a resulting in different epidermolysis bullosa simplex phenotypes," Journal of Investigative Dermatology, vol. 117, no. 5, pp. 1103-1107, 2001.

[88] T. Kobayashi, K. Narahara, Y. Yokoyama et al., "Gardner syndrome in a boy with interstitial deletion of the long arm of chromosome 5," American Journal of Medical Genetics, vol. 41, no. 4, pp. 460-463, 1991.

[89] M. Ehrenreich, M. M. Tarlow, E. Godlewska-Janusz, and R. A. Schwartz, "Incontinentia pigmenti (Bloch-Sulzberger syndrome): a systemic disorder," Cutis, vol. 79, no. 5, pp. 355$362,2007$.

[90] N. V. Whittock, C. M. Coleman, W. H. I. Mclean et al., "The gene for Naegeli-Franceschetti-Jadassohn syndrome maps to 17q21," Journal of Investigative Dermatology, vol. 115, no. 4, pp. 694-698, 2000.
[91] T. C. Hart, P. S. Hart, D. W. Bowden et al., "Mutations of the cathepsin $\mathrm{C}$ gene are responsible for Papillon-Lefévre syndrome," Journal of Medical Genetics, vol. 36, no. 12, pp. 881-887, 1999.

[92] M. Pigg, S. Jagell, A. Sillén, J. Weissenbach, K. H. Gustavson, and C. Wadelius, "The Sjögren-Larsson syndrome gene is close to D17S805 as determined by linkage analysis and allelic association," Nature Genetics, vol. 8, no. 4, pp. 361-364, 1994.

[93] V. de Laurenzi, G. R. Rogers, D. J. Hamrock et al., "SjögrenLarsson syndrome is caused by mutations in the fatty aldehyde dehydrogenase gene," Nature Genetics, vol. 12, no. 1, pp. 52-57, 1996.

[94] C. Estrela, A. H. G. de Alencar, G. T. Kitten, E. F. Vencio, and E. Gava, "Mesenchymal stem cells in the dental tissues: perspectives for tissue regeneration," Brazilian Dental Journal, vol. 22, no. 2, pp. 91-98, 2011.

[95] P. C. B. Beltrão-Braga, G. C. Pignatari, P. C. Maiorka et al., "Feeder-free derivation of induced pluripotent stem cells from human immature dental pulp stem cells," Cell Transplantation, vol. 20, no. 11-12, pp. 1707-1719, 2011.

[96] J. Hanna, M. Wernig, S. L. Markoulaki et al., "Treatment of sickle cell anemia mouse model with iPS cells generated from autologous skin," Science, vol. 318, no. 5858, pp. 1920-1923, 2007.

[97] R. R. Nadig, "Stem cell therapy-hype or hope? A review," Journal of Conservative Dentistry, vol. 12, no. 4, pp. 131-138, 2009.

[98] T. Yoshida, K. Washio, T. Iwata, T. Okano, and I. Ishikawa, "Current status and future development of cell transplantation therapy for periodontal tissue regeneration," International Journal of Dentistry, vol. 2012, Article ID 307024, 8 pages, 2012.

[99] S. Sood, S. Gupta, and A. Mahendra, "Gene therapy with growth factors for periodontal tissue engineering-a review," Medicina Oral, Patología Oral y Cirugía Bucal, vol. 12, no. 2, pp. e301-e310, 2012.

[100] J. E. Nör, "Tooth regeneration in operative dentistry," Operative Dentistry, vol. 31, no. 6, pp. 633-642, 2006.

[101] F. F. Demarco, M. C. M. Conde, B. N. Cavalcanti, L. Casagrande, V. T. Sakai, and J. E. Nör, "Dental pulp tissue engineering," Brazilian Dental Journal, vol. 22, no. 1, pp. 3$14,2011$. 

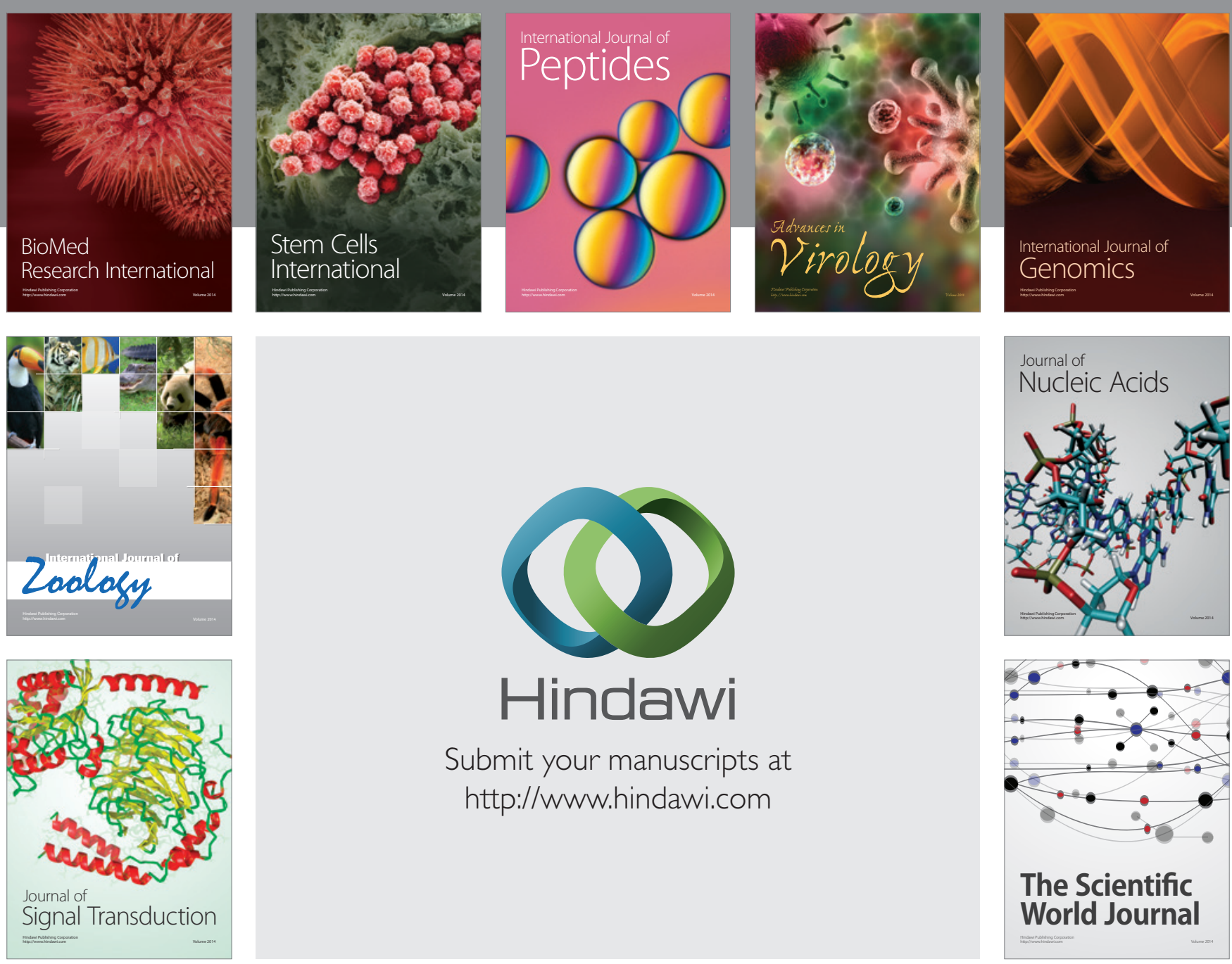

Submit your manuscripts at

http://www.hindawi.com
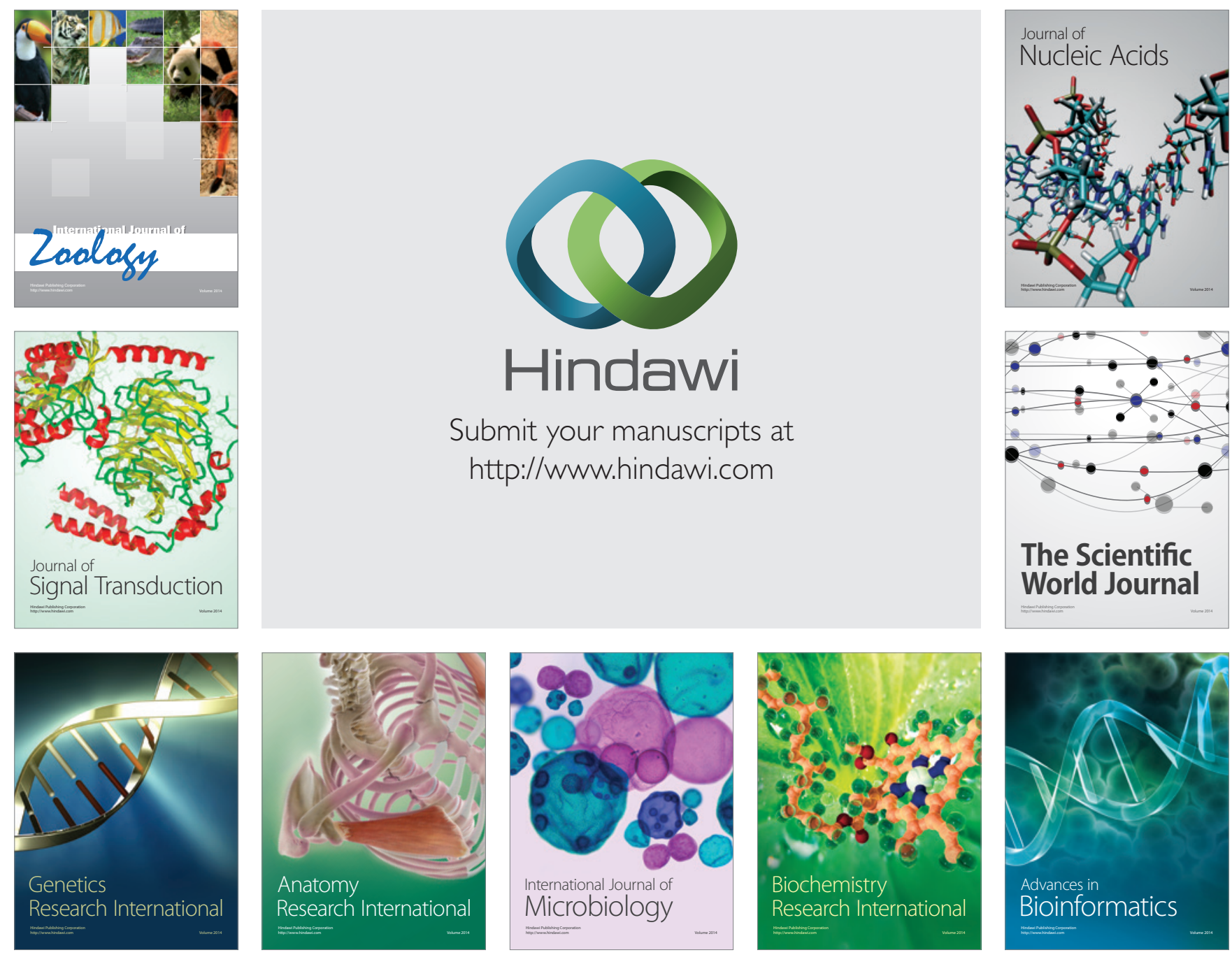

The Scientific World Journal
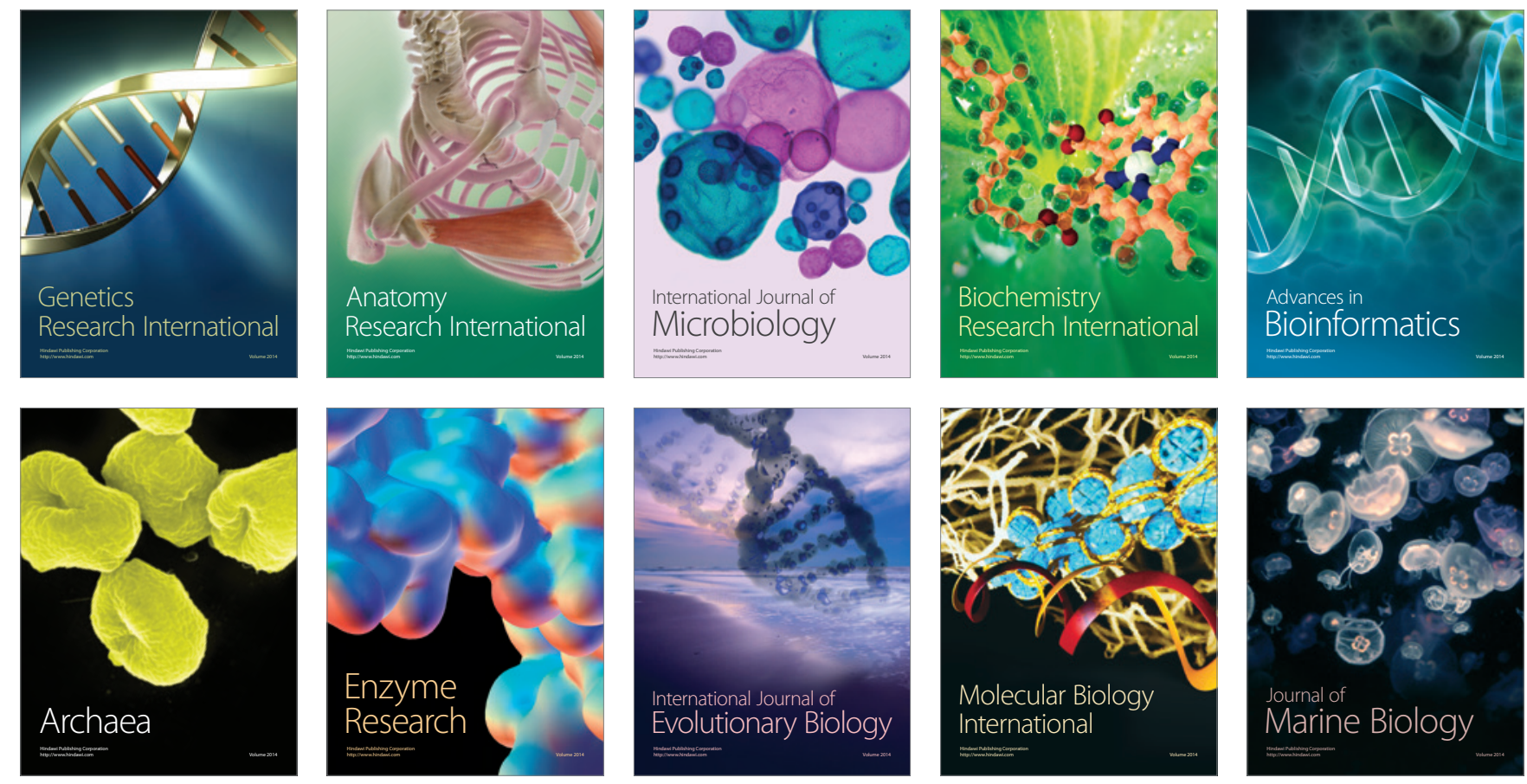